\title{
THIODICARB SEED TREATMENT FOR THE PROTECTION OF SEEDLING RYEGRASS FROM ARGENTINE STEM WEEVIL LARVAE
}

\author{
P.J. ADDISON, G.M. BARKER and A.C. FIRTH
}

AgResearch, Ruakura Agricultural Centre, Private Bag 3123, Hamilton

\section{SUMMARY}

Two outdoor trials in troughs and one screenhouse pot trial were conducted using thiodicarb and the standard, furathiocarb, applied to ryegrass (Lolium multiflorum L.) at $1 \%$ of seed weight. Isazophos was applied at $1.0 \mathrm{~kg} / \mathrm{ha}$ as in-furrow granules in one trial. In the presence of Argentine stem weevil (Listronotus bonariensis (Kuschel)) larvae, all insecticides were similarly effective in increasing seedling emergence and survival over that of untreated seed. In these trials thiodicarb had no adverse effect on ryegrass germination or early seedling growth. Keywords: Argentine stem weevil, Listronotus bonariensis, seedling damage, thiodicarb, seed treatment.

\section{INTRODUCTION}

Argentine stem weevil (ASW) is a major pest of improved pastures in New Zealand with damage estimated to cost \$78-251M annually (Prestidge et al. 1991). Most grasses are favourable hosts for both adult foliar feeding and larval stem boring (Goldson 1982; Barker 1989). Adult defoliation at ground level, larval feeding on the developing stem before or soon after emergence and larval stem boring in older seedlings can greatly reduce grass establishment. Insecticide protection at sowing can significantly enhance grass establishment in the presence of ASW (Trought 1976).

A systemic insecticide applied to seed is ideally placed to protect seedling grass from foliar feeding pests such as ASW, as the chemical is rapidly absorbed and translocated into the stem and leaves of the developing seedling (Trought 1976; Barker et al. 1991). Seed treatment requires less active ingredient than in-furrow or blanket pesticide applications and is therefore less costly.

This paper reports on trials to evaluate the systemic carbamate insecticide, thiodicarb, as a seed treatment for the protection of ryegrass seedlings from damage by ASW larvae.

\section{METHODS}

Outdoor trials in troughs and a screenhouse pot trial were conducted using thiodicarb (Larvin $75 \mathrm{WP}$ ) applied to seed of short rotation ryegrass (cv. 'Concord'). Furathiocarb (Promet 800 SCO) seed treatment (three trials) and isazophos (Miral 10 G) (one trial) were included for comparison.

Trial 1

On 8 January 1991, 30 ASW adults were confined in $16 \mathrm{~cm}$ square pots containing established ryegrass plants for a period of five days and then removed. On 25 January 1991 the pots were sprayed with glyphosate (Roundup) herbicide at a rate equivalent to $1080 \mathrm{~g} / \mathrm{ha}$. Seed (coated 3 months prior to trial) and in-furrow granular treatments (Table 1) were applied at sowing 4 days after herbicide application. For each treatment 15 ryegrass seeds were sown in each of two $16 \mathrm{~cm}$ long furrows per pot to simulate direct drill conditions. The isazophos granules were applied in the furrow with untreated seed at a rate equating to $1.0 \mathrm{~kg} / \mathrm{ha}$ at $15 \mathrm{~cm}$ row spacings. There were four replicates of each treatment. Seedling numbers were recorded 7,12 and 16 days after sowing.

Proc. 46th N.Z. Plant Protection Conf. 1993: 224-227 
The viability of treated and untreated seed was determined by placing 100 seeds on moist filter paper in Petri dishes. Germination was recorded after 15 days. Trial 2

On 25 October $1991,150\left(=370 / \mathrm{m}^{2}\right)$ ASW adults were confined in plastic troughs $0.9 \mathrm{~m} \times 0.45 \mathrm{~m}$ containing established ryegrass plants for a period of 7 days and then removed. The ryegrass in the troughs was sprayed with glyphosate herbicide at 1080 $\mathrm{g} /$ ha on 5 November 1991. Three days later 30 seeds of each seed treatment (Table 1) were sown in $1 \mathrm{~cm}$ deep furrows cut in the trough turf to simulate direct drilling conditions. Each of the treatments were sown in randomised $45 \mathrm{~cm}$ long furrows in each of eight replicate troughs. Seedling numbers were recorded 10,17 and 26 days after sowing.

The viability of untreated and treated seed was determined by placing 50 seeds on moist filter paper in Petri dishes and recording germination after 12 days. Emergence and survival of untreated seed in soil free of ASW larvae was assessed.

Trial 3

On 30 January 1992, thirty seeds of each treatment (Table 2) were sown into troughs $0.9 \mathrm{~m} \times 0.45 \mathrm{~m}$ with soil containing approximately 1500 buried ryegrass tillers, thus simulating a cultivated seed bed. One half of the troughs contained ASW egg and larval infested tillers ( 35 eggs and 18 larvae/200 tillers), the remainder contained no ASW eggs or larvae. Each of the treatments were sown in randomised $45 \mathrm{~cm}$ long rows in each of six replicate troughs.

Seedling emergence was recorded 9 days after sowing. Fifteen days after sowing, the remaining seedlings were counted and harvested at ground level for foliar dry matter yield.

The data from all trials were subjected to analysis of variance.

TABLE 1: Germination on filter paper and emergence and survival of ryegrass seedlings in the presence or absence of ASW larvae as influenced by thiodicarb and furathiocarb seed treatments and isazophos granules.

\begin{tabular}{|c|c|c|c|c|}
\hline Treatment & & $\begin{array}{l}\% \text { germination } \\
\text { of seed on } \\
\text { moist filter } \\
\text { paper }^{1}\end{array}$ & $\begin{array}{l}\text { Total number } \\
\text { of emergent } \\
\text { seedlings out } \\
\text { of } 30 \text { sown }\end{array}$ & $\begin{array}{l}\text { Number of } \\
\text { seedlings } \\
\text { remaining at } \\
\text { trial conclusion }\end{array}$ \\
\hline $\begin{array}{l}\text { Trial 1 } \\
\text { untreated } \\
\text { isazophos } \\
\text { thiodicarb } \\
\text { furathiocarb } \\
\text { untreated } \\
\text { (no ASW) } \\
\text { LSD }_{(5 \%)}\end{array}$ & $\begin{array}{l}1.0 \mathrm{~kg} \mathrm{ai} / \mathrm{ha} \\
1.0 \mathrm{~kg} \mathrm{ai} / 100 \mathrm{~kg} \text { seed } \\
1.0 \mathrm{~kg} \mathrm{ai} / 100 \mathrm{~kg} \text { seed } \\
-\end{array}$ & $\begin{array}{l}94(88-98) \\
- \\
88(80-94) \\
76(67-84) \\
-\end{array}$ & $\begin{array}{r}20.8 \\
25.0 \\
25.5 \\
20.8 \\
28.3 \\
\\
5.7\end{array}$ & $\begin{array}{l}19.8 \\
24.8 \\
25.3 \\
20.8 \\
28.3\end{array}$ \\
\hline $\begin{array}{l}\text { Trial } 2 \\
\text { untreated } \\
\text { thiodicarb } \\
\text { furathiocarb } \\
\text { untreated } \\
\text { (no ASW) } \\
\text { LSD }_{(5 \%)}\end{array}$ & $\begin{array}{l}1.0 \mathrm{~kg} \mathrm{ai} / 100 \mathrm{~kg} \text { seed } \\
1.0 \mathrm{~kg} \mathrm{ai} / 100 \mathrm{~kg} \text { seed } \\
-\end{array}$ & $\begin{array}{l}98(89-100) \\
94(83-99) \\
90(78-97) \\
-\end{array}$ & $\begin{array}{r}19.2 \\
25.3 \\
23.1 \\
28.6 \\
\\
3.8\end{array}$ & $\begin{array}{r}8.8 \\
13.4 \\
16.6 \\
28.3 \\
\\
4.4\end{array}$ \\
\hline
\end{tabular}

${ }^{1}(95 \%$ confidence intervals)

2 Trial one 16 days after sowing; Trial two 26 days after sowing 
Trial 1

\section{RESULTS}

Thiodicarb seed treatment had no effect on germination (Table 1). Furathiocarb reduced germination of the ryegrass seed $(P<0.05)$. Seedling vigour was not visibly affected by either seed treatment.

ASW larvae reduced emergence of seedlings from untreated seed $(\mathrm{P}<0.01)$. Emergence was similar for each insecticide treatment in the presence of ASW larvae.

Thiodicarb seed treatment increased the number of seedlings remaining 16 days after sowing compared to untreated seed $(\mathrm{P}<0.05)$. Only with thiodicarb seed treatment and isazophos granules was emergence and survival of seedlings in the presence of larvae maintained at a similar level to that of ASW-free pots.

Trial 2

Germination was unaffected by seed treatment (Table 1) and no visible phytotoxic symptoms were evident in the seedlings.

ASW larvae reduced emergence $(P<0.01)$ and survival $(P<0.001)$ of seedlings produced from untreated seed (Table 1). A similar proportion of seedlings were damaged pre- and post-emergence. Seedling emergence in the presence of ASW larvae was increased by both thiodicarb and furathiocarb seed treatments compared to untreated seed $(\mathrm{P}<0.05)$. Emergence of seedlings from thiodicarb treated seed did not differ from that in 'no larvae' troughs.

Thiodicarb and furathiocarb seed treatments increased seedling survival $(\mathrm{P}<0.05$ and $\mathrm{P}<0.01$ respectively) over seedlings from untreated seed but numbers of seedlings established was only $47-59 \%$ of that in the absence of larvae.

Trial 3

Thiodicarb and furathiocarb seed treatments had no influence on emergence, survival or yield of ryegrass seedlings in the absence of larvae (Table 2). The presence of larvae reduced emergence $(\mathrm{P}<0.05)$, survival $(\mathrm{P}<0.001)$ and yield $(\mathrm{P}<0.001)$ of seedlings from untreated seed. Seed treatment increased seedling emergence $(\mathrm{P}<0.05)$ over untreated seed, with levels comparable to that in 'no larvae' troughs.

Seed treatment increased seedling survival $(\mathrm{P}<0.05)$ and yield $(\mathrm{P}<0.01)$ in larval infested troughs compared to seedlings from untreated seed, but only to levels approximately half those in 'no larvae' troughs.

TABLE 2: Emergence and survival of ryegrass seedlings in the presence or absence of ASW larvae as influenced by thiodicarb and furathiocarb seed treatments.

\begin{tabular}{|c|c|c|c|c|c|c|c|}
\hline \multirow[t]{2}{*}{ Treatment } & \multirow[t]{2}{*}{$\begin{array}{c}\text { Rate } \\
\text { (kg ai/100 kg seed) }\end{array}$} & \multicolumn{2}{|c|}{$\begin{array}{c}\text { Total number } \\
\text { of emergent } \\
\text { seedlings out } \\
\text { of } 30 \text { sown }\end{array}$} & \multicolumn{2}{|c|}{$\begin{array}{l}\text { Number of } \\
\text { seedlings remaining } \\
15 \text { days after } \\
\text { sowing }\end{array}$} & \multicolumn{2}{|c|}{$\begin{array}{l}\text { Dry matter } \\
\text { yields } 15 \text { days } \\
\text { after sowing } \\
\text { (mg/trough) }\end{array}$} \\
\hline & & No larvae & Larvae & No larvae & Larvae & No larvae & Larvae \\
\hline untreated & - & 28.8 & 22.5 & 28.5 & 9.2 & 89.2 & 19.7 \\
\hline thiodicarb & 1.0 & 29.0 & 27.0 & 28.5 & 16.0 & 81.2 & 44.3 \\
\hline furathiocarb & 1.0 & 29.0 & 26.1 & 29.0 & 14.2 & 91.8 & 43.5 \\
\hline $\operatorname{LSD}_{(5 \%)}$ & & \multicolumn{2}{|c|}{3.5} & \multicolumn{2}{|c|}{4.6} & \multicolumn{2}{|c|}{16.2} \\
\hline
\end{tabular}

DISCUSSION

Three categories of ASW larval damage were recognised in the newly sown ryegrass; (1) feeding below the soil surface before seedling emergence; (2) cutting at or near the soil surface and; (3) larval tunnelling within the seedlings. Pre-emergence and cutting damage accounted for most seedling mortalities occurring in the trials. The thin nature of the newly emerged ryegrass stems precluded stem boring for all but the smallest larvae. Larger larvae foraged on the soil surface, cutting and killing a number of seedlings. 
Thiodicarb applied as a $1 \%$ seed coating to short rotation ryegrass seed reduced all categories of larval damage. Seedling emergence and survival were enhanced to a level similar to that for furathiocarb treated seed and isazophos granules. Robertson (1991) reported similar efficacies of thiodicarb and furathiocarb against black field earwig (Nala lividipes (Dufour)) when applied as $0.7 \%(\mathrm{w} / \mathrm{w})$ seed coatings to cotton seed.

Seedling establishment from treated seed under the high larval pressures encountered in Trials 2 and 3, was only approximately half that in larval free troughs. These trials probably represent the worst scenario; larval populations are unlikely to be of the same magnitude during establishment of grass seedlings in the field.

Thiodicarb is currently registered in New Zealand for use as a seed coating for grasses against stem weevil and forage brassicas against springtails. The results of the present work support the claim that thiodicarb applied to ryegrass seed at $1 \%$ of seed weight is an effective protectant against ASW larvae, with no apparent phytotoxicity.

\section{ACKNOWLEDGEMENTS}

The authors thank Rhône-Poulenc NZ Ltd for the financial and technical assistance provided during the course of the trials.

\section{REFERENCES}

Barker, G.M., 1989. Grass host preferences of Listronotus bonariensis (Coleoptera: Curculionidae). Econ. Ent. 86: 1807-1816.

Barker, G.M., Addison, P.J. and Robertson, L.N., 1991. Glasshouse evaluations of seed treatments for protection of ryegrass seedling from insect pests. Proc. 44th N.Z. Weed and Pest Control Conf.: 189-194.

Goldson, S.L., 1982. An examination of the relationship between Argentine stem weevil (Listronotus bonariensis (Kuschel)) and several of its host grasses. N.Z.J. Ag. Res. 25: 395-403.

Prestidge, R.A., Barker, G.M. and Pottinger, R.P., 1991. The economic cost of Argentine stem weevil in pastures in New Zealand. Proc. 44th N.Z. Weed and Pest Control Conf.: 165-170.

Robertson, L.N., 1991. Soil-insecticide bioassays and seed treatments for soil-insect control in Central Queensland, Australia. Crop Protection 10: 293-298.

Trought, T.E.T., 1976. Control of Argentine stem weevil in seedling ryegrass. Proc. 29th N.Z. Weed and Pest Control Conf.: 203-206. 